\title{
Chapter 7 \\ Mutations Observed in Mitochondrial \\ DNA of Salmon Collected in Mano River, \\ Fukushima Prefecture, Japan
}

\author{
Muhammad Fitri Bin Yusof, Gyo Kawada, Masahiro Enomoto, \\ Atsushi Tomiya, Masato Watanabe, Daigo Morishita, Shigehiko Izumi, \\ and Masamichi Nakajima
}

\begin{abstract}
On March 11, 2011, a great earthquake occurred off the east coast of Honshu Island, Japan. The consequent breakdown of the Fukushima Daiichi Nuclear Power Plant (FDNPP) caused a massive release of radionuclides into terrestrial and marine environments and into the atmosphere. The Abukuma Mountains region is one of the areas highly polluted by this accident. Freshwater fishes continued to live in this area after the FNPP accident became so polluted.

Mitochondrial DNA (mtDNA) usually transfers from the mother to the next generation clonally. Therefore, it is one of the best genetic predictors of the effect of radiation on DNA. The influence of radiation can be presumed by comparing mtDNA between larval fish and their female parent. mtDNA of masu salmon was collected from an area highly polluted, namely, the upstream portion of Mano River, and compared it with that from nonpolluted cultured masu salmon.

While no mutations were observed in the cultured masu salmon, those collected from Mano River exhibited three types of subdivisions in the Cytb region and two types of subdivisions in the D-loop region of mtDNA. These results suggest that exposure to radioactive cesium causes a base exchange in DNA. But the mutations observed were not serious enough to affect the masu salmon phenotype.
\end{abstract}

Keywords Mitochondrial DNA · Mutation $\cdot$ Cytb $\cdot$ D-loop $\cdot$ Oncorhynchus masou · Fukushima

\footnotetext{
M. F. B. Yusof · M. Nakajima $(\bowtie)$

Graduate School of Agricultural Science, Tohoku University, Sendai, Japan

e-mail: Masamichi.nakajima.b6@tohoku.ac.jp

G. Kawada · M. Enomoto · A. Tomiya · M. Watanabe · D. Morishita · S. Izumi

Fukushima Inland Water Fisheries Experimantal Station, Inawashiro, Fukushima, Japan
} 


\subsection{The Fukushima Daiichi Nuclear Power Plant Accident}

On March 11, 2011, a great earthquake measuring 9.0 on the Richter scale occurred off the east coast of Honshu Island, Japan. It caused a huge tsunami, which struck eastern Japan and broke down the cooling system of the reactors at Fukushima Daiichi Nuclear Power Plant (FDNPP). The breakdown caused a massive release of radionuclides into terrestrial and marine environments as well as into the atmosphere. This raised a huge concern globally about how far the radionuclides would travel around the world, and their biological influences on living organisms. It also increased uneasiness among people about the long-term effect of radionuclides on ecosystems and on the next generation of humans. Precise information on what occurred and on what is ongoing has yet to be investigated. The collapse of FDNPP caused a massive release of radioactive materials into the environment [1-3]. Various potential threats to ecosystems and to living organisms were reported $[4,5]$. The released radioactivity can affect an organism's genetic structure and ecosystem. More importantly, radionuclides will accumulate in the bodies of organisms and thus will be transmitted through the food chain.

The main radioactive materials that affect organisms are cesium-134 $\left({ }^{134} \mathrm{Cs}\right)$ and cesium-137 $\left({ }^{137} \mathrm{Cs}\right)$, because these materials have comparatively long half-lives of 2 and 30 years, respectively. During the decay process, these materials emit $\gamma$-rays and $\beta$-particles [6]. In addition, exposure to high-dose radioactive $\mathrm{Cs}$ is clastogenic to chromosomes, increases mutation rates and can be transmitted to the next generation $[7,8]$.

\subsection{The Genetic Effects of Radiation on Organisms}

Various effects of radiation have been examined since radiation was discovered. Since Muller [9] suggested that X-rays cause mutations in Drosophila, it has been well known that X-rays and other forms of radiation lead to genetic mutations. Casarett [10] reported the influence of radiation on mammals such as mice. In the case of fishes, many studies have examined the genetic effects of X-rays and $\gamma$-rays from the 1960s to the 1980s [11-13] in guppy (Poecilia reticulata) and medaka (Oryzias latipes). These studies used relatively high dose of external radiation. On the other hand, in the case of the FDNPP accident, it is necessary to consider the effect of internal low-dose and long-term exposure to radioactive substances. Little is known about the effect of long-term exposure to low levels of radioactive substances such as ${ }^{137} \mathrm{Cs}$. The effect of ${ }^{137} \mathrm{Cs}$ contamination on organisms should be elucidated, especially with regard to changes in chromosome structure, gametes, molecular structure and DNA sequence. 


\subsection{The Situation of Freshwater Fishes in Fukushima}

A large amount of radioactive Cs was released into the atmosphere as a result of the FDNPP accident in March 2011. Chino et al. [14] estimated the total amount of released radioactive materials until April 2011, as follows: iodine-131 ( $\left.{ }^{131} \mathrm{I}\right)$ was 1.5 $\times 10^{17} \mathrm{~Bq}$ and ${ }^{137} \mathrm{Cs}$ was $1.2 \times 10^{16} \mathrm{~Bq}$. On the other hand, Stohl et al. [15] estimated the released radioactive materials as follows: Xenon-133 $\left({ }^{133} \mathrm{Xe}\right)$ was $1.24 \times 10^{19} \mathrm{~Bq}$ and ${ }^{137} \mathrm{Cs}$ was $2.94 \times 10^{18} \mathrm{~Bq}$. Radioactive $\mathrm{Cs}$ travels through both air and water systems, and in this case, it contaminated most aquatic organisms across a vast area $[1,16,17]$. The Abukuma Mountains area is one of the areas highly polluted by the accident. Radioactive pollution in the freshwater area in the Abukuma Mountains continues to the present [18-20] (as of August, 2019, http://fikushima-radioactivity. $\mathrm{jp} / \mathrm{pc} /$ ). Freshwater fishes have continued to live in this polluted environment after the accident.

Masu salmon (Oncorhynchus masou), belongings to the salmonid family of genus Oncorhynchus, is widely distributed in Russia, Korea, and Japan, including the Abukuma Mountains. In Japan, they are distributed mainly in the coastal area of the Sea of Okhotsk, the Northern Pacific Ocean and the Northern Sea of Japan [21, 22]. However, masu salmons are found in all areas of Mano River where sampling was performed in this study; their distribution between upstream and downstream is separated by Hayama dam. The upstream salmons are separated from the downstream population and spend their life cycle in the dam lake and the upper stream. The individuals collected from Hayama Lake and its upper stream had spent 2-3 years in this ecosystem polluted by radionuclides from the FDNPP accident.

\subsection{Use of Gynogenesis to Estimate Mutation Rate}

Mitochondrial DNA (mtDNA) is one of the best genetic predictors of the effect of radiation on DNA because mtDNA usually transfers to the next generation clonally. mtDNA also has a higher mutation rate than genomic DNA [23]. It is expected that mtDNA is more sensitive to radiation than genomic DNA. Because a cell contains thousands of copies of mitochondria, there is a possibility of heteroplasmy. But, since it was reported that heteroplasmic mtDNA quickly return to homoplasmy, it can be assumed that the fundamental haplotype of each individual is homoplasmic and monomorphic [24]. Gynogenesis involves the production of diploid eggs in which both chromosome sets are obtained from the maternal half. An example of paternal inheritance was also reported, but it is a very rare occurrence [25]. The influence of mtDNA from the male parent can be excluded more certainly by using artificial gynogenesis technology. It is expected that the offspring obtained from a single female will possess basically the same DNA sequence. Fitri et al. (unpublished) compared the sequences of two regions of mtDNA of offspring obtained from two females collected from Mano River in Fukushima Prefecture against those 
collected from two cultured females from the Fukushima Prefectural Inland Water Fisheries Experimental Station (FPIWFES).

The application of artificial gynogenesis technology to fish was established in the 1980s [26]. This technology was used to examine the production of tetraploid, polyploid and clonal fishes, and these attempts succeeded in many fishes and shellfishes. The clonalization of mtDNA in masu salmon using artificial gynogenetic technology is not difficult. The influence of radiation can be presumed by examining what happens in the mtDNA introduced from a dam as a clone larval fish.

\subsection{Genetic Analysis in This Study}

\subsubsection{Materials and Methods}

Masu salmons that had swum upstream to spawn were collected from Mano River upstream of Hayama Lake (Fig. 7.1). The fishes examined in this study were some of those individuals. We succeeded in obtaining gynogenetic offspring from two females from Mano River and two cultured females from the FPIWFES.

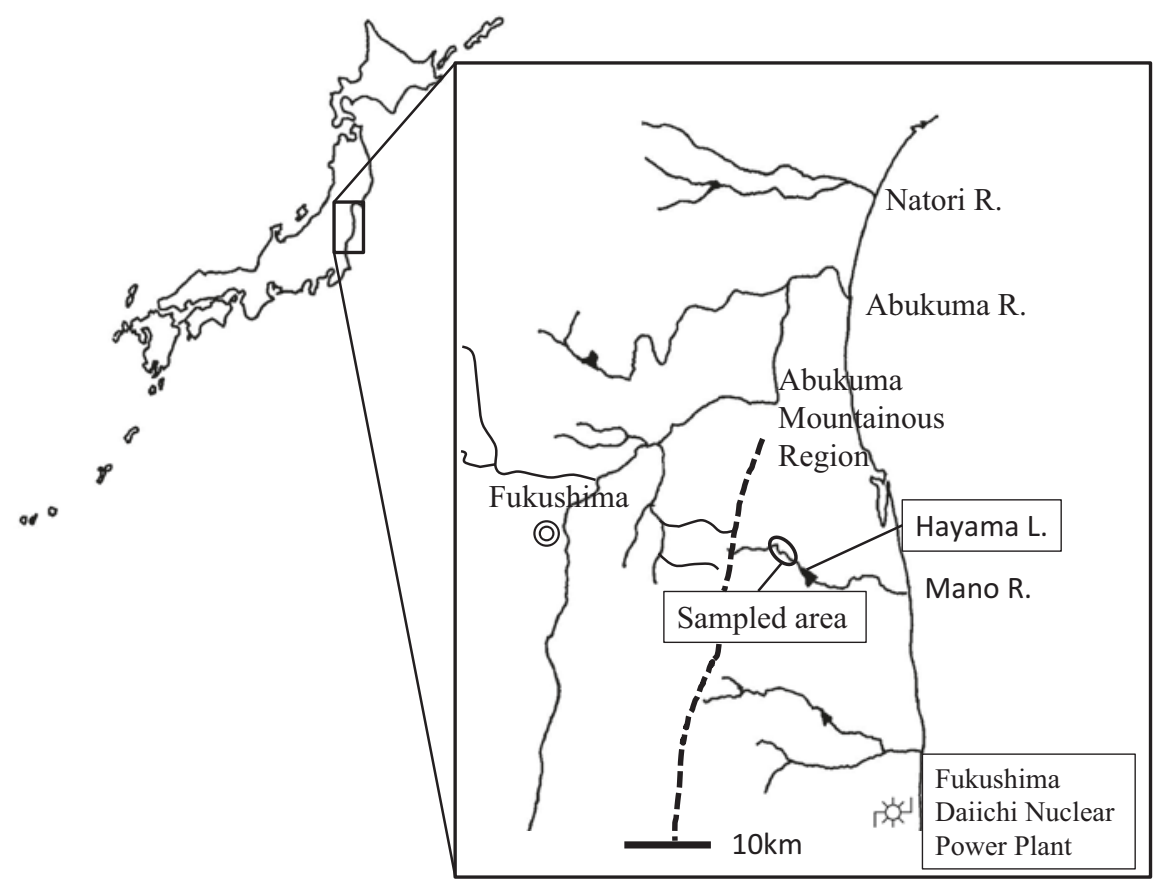

Fig. 7.1 Locations of sample collection, Mano River, Fukushima 
Table 7.1 Used microsatellite DNA markers in this study and their forward and reverse primers

\begin{tabular}{|c|c|c|c|}
\hline \multirow[b]{2}{*}{ Locus } & \multirow{2}{*}{$\begin{array}{l}\text { Repeat sequence of cloned } \\
\text { allele }\end{array}$} & Primer sequence $\left(5^{\prime}-3^{\prime}\right)$ & \multirow{2}{*}{$\begin{array}{l}\text { GenBank } \\
\text { no. }\end{array}$} \\
\hline & & (F, forward; $\mathrm{R}$, reverse) & \\
\hline \multirow[t]{2}{*}{ One102 } & \multirow[t]{2}{*}{$(\mathrm{ATCT}) 10$} & F: CATGGAGAAAAGACCAATCA & \multirow[t]{2}{*}{ AF274518 } \\
\hline & & R: TCACTGCCCTACAACAGAAG & \\
\hline \multirow[t]{2}{*}{ One114 } & (TAGA)12N4 & F: TCATTAATCTAGGCTTGTCAGC & \multirow[t]{2}{*}{ AF274530 } \\
\hline & $(\mathrm{TAGA}) 12$ & R: TGCAGGTAAGACAAGGTATCC & \\
\hline \multirow[t]{2}{*}{ Oke308 } & \multirow[t]{2}{*}{$($ AGAT) 19} & $\begin{array}{l}\text { F: } \\
\text { AAGAGCAGAGGGAGAAATGGA }\end{array}$ & \\
\hline & & R: GTTGTTTGGATGGGAAGTGG & \\
\hline
\end{tabular}

DNA was extracted from the tail fin using a DNA extraction kit (DNeasy Blood and Tissue Kit, Qiagen). Extracted DNA was used for parentage analysis and for the detection of mutations at two regions of mtDNA: Cytb and D-loop. For parentage analysis, three microsatellite primer sets were used: One102, One114 [27] and Oke308 (Kudo et al. unpublished). The primer set of each microsatellite locus is presented in Table 7.1. Primer sets corresponding to Cytb and D-loop were synthesized with reference to the mtDNA sequence of NCBI database. The forward and reverse primers of Cytb were 5'-GCCATGCACTACACCTCAGA-3' and 5'-GTTCTACGGGTATGCCTCCG-3'. The primers of D-loop were 5'-ACATCAGCACAACTCCAAGGT-3' and 5'-CGGTGCCAGGTGCTGTTA-3' . Forward and reverse sequencing analyses were performed using the $3500 \mathrm{XL}$ Genetic Analyzer (Life Technologies).

\subsubsection{Results}

\subsubsection{Parentage Analysis}

The identified genotypes of the female parent and the segregation of the offspring are presented in Table 7.2. Each maternal individual, M5 and M6, was identified by three loci of microsatellite markers, because these two maternal individuals had no common allele in the three loci examined. In One102, the genotype of M5 was 290/242; that of M6 was 262/225. The expected genotypes of the offspring in M5 were 290/290 and 242/242, and those of the offspring in M6 were 262/262 and $225 / 225$. In the offspring, only the alleles that existed in the maternal parent were observed. This phenomenon was observed also in the other two microsatellite markers. These results exclude the possibility that the individual's mixture came from another family. 
Table 7.2 Segregated genotypes observed in each locus of each family

\begin{tabular}{l|l|l|l|l}
\hline Locus & Family & Maternal genotype & Segregated genotype & No. of individuals \\
\hline \multirow{4}{*}{ One102 } & M5 & $290 / 242$ & $290 / 290$ & 9 \\
\cline { 2 - 5 } & & & $242 / 242$ & 5 \\
\cline { 2 - 5 } & M6 & $262 / 225$ & $262 / 262$ & 11 \\
\cline { 2 - 5 } & & & $225 / 225$ & 5 \\
\hline \multirow{5}{*}{ One114 } & M5 & $313 / 217$ & $313 / 313$ & 7 \\
\cline { 2 - 5 } & & & $217 / 217$ & 6 \\
\cline { 2 - 5 } & M6 & $281 / 253$ & $281 / 281$ & 13 \\
\cline { 2 - 5 } & & & $253 / 253$ & 5 \\
\hline & M5 & $246 / 246$ & $246 / 246$ & 11 \\
\cline { 2 - 5 } & & $290 / 234$ & $290 / 290$ & 5 \\
\hline
\end{tabular}

Table 7.3 Samples used in this study

\begin{tabular}{l|l|l|l|c|c}
\hline Collected area & Female parent & Number of examined individuals & Age & ${ }^{134} \mathrm{Cs}^{\mathrm{a}}$ & ${ }^{137} \mathrm{Cs}^{\mathrm{a}}$ \\
\hline \multirow{2}{*}{ Mano River } & M5 & 20 & 2 & 156.0 & 476.0 \\
\cline { 2 - 6 } & M6 & 22 & 1 & 62.6 & 149.0 \\
\hline \multirow{2}{*}{ FPIWFES } & FP9 & 50 & 2 & 0 & 0 \\
\cline { 2 - 6 } & FP23 & 50 & 2 & 0 & 0 \\
\hline
\end{tabular}

${ }^{\mathrm{a}} \mathrm{Bq} / \mathrm{kg}$

FPIWFES Fukushima Prefectural Inland Water Fisheries Experimental Station

\subsubsection{Observed Mutations and Estimated Mutation Rate in Mitochondrial DNA of Masu Salmon}

A total of 42 offsprings from Mano River, 20 from M5 and 22 from M6, were examined (Table 7.3). The concentrations of radioactive Cs in muscle tissues of M5 and M6 females were 632.0 and $211.6 \mathrm{~Bq} / \mathrm{kg}$, respectively. On the other hand, radioactive Cs in muscle tissue was undetectable in all of 100 offsprings from the FPIWFES ( 50 from FP9 and 50 from FP23). Although an estimated 800 bases were acquired from direct sequencing, only 765 bases were analyzed (bases 207-972).

In the Cytb region, four types of substitutions were observed. In the offspring of M5, substitutions were observed at the 324th, 697th, and 795th bases (Table 7.4). Among the four types of substitutions, amino acid substitution was observed in two types, Ala to Thr and Thr to Ala, caused by G to A and A to G base substitutions, respectively. In the M6 offspring, base substitutions were observed in the same positions as in the M5 offspring. In the D-loop region, substitutions were observed only in two M6 offspring. In these two offspring, two types of substitutions were observed at the 299th and 623rd bases, which were G to A and T to C, respectively (Table 7.5). It is possible to consider these base substitutions are caused by exposure to radioactive Cs. The individuals observed substitution have the alleles which from maternal 
Table 7.4 Mutations observed in the Cytb region

\begin{tabular}{l|l|l|l|l|l}
\hline $\begin{array}{l}\text { Female } \\
\text { parent }\end{array}$ & $\begin{array}{l}\text { Base } \\
\text { position }\end{array}$ & $\begin{array}{l}\text { Type of } \\
\text { substitution }\end{array}$ & $\begin{array}{l}\text { Amino acid } \\
\text { change }\end{array}$ & $\begin{array}{l}\text { Observed number } \\
\text { of individuals }\end{array}$ & Mutation rate \\
\hline M5 & 324 & T $>$ A & Leu $>$ Leu & 1 & $8.04 \times 10^{-6}$ \\
\hline M6 & 324 & T $>$ G & Leu $>$ Leu & 1 & $1.29 \times 10^{-5}$ \\
\hline M5 & 697 & G $>$ A & Ala $>$ Thr & 1 & $8.04 \times 10^{-6}$ \\
\hline M6 & 697 & A $>$ G & Thr $>$ Ala & 1 & $4.9 \times 10^{-6}$ \\
\hline M5 & 795 & G $>$ A & Pro $>$ Pro & 2 & $3.1 \times 10^{-5}$ \\
\hline M6 & 795 & A $>$ G & Pro $>$ Pro & 1 & $4.9 \times 10^{-6}$ \\
\hline
\end{tabular}

Table 7.5 Mutations observed in the D-loop region

\begin{tabular}{l|l|l|l|l}
\hline $\begin{array}{l}\text { Female } \\
\text { parent }\end{array}$ & $\begin{array}{l}\text { Base } \\
\text { position }\end{array}$ & $\begin{array}{l}\text { Type of } \\
\text { substitution }\end{array}$ & $\begin{array}{l}\text { Observed number of } \\
\text { individual }\end{array}$ & $\begin{array}{l}\text { Mutation } \\
\text { rate }\end{array}$ \\
\hline M6 & 299 & G $>$ A & 2 & $1.76 \times 10^{-5}$ \\
\hline M6 & 623 & T $>$ C & 2 & $1.76 \times 10^{-5}$ \\
\hline
\end{tabular}

individual in microsatellite analysis, can exclude the possibility of contamination from other individuals. No mutation was observed in the samples from the captive maternal parents of $\mathrm{PF} 9$ and $\mathrm{PF} 23$. The Cytb region is a coding region in mtDNA. It codes for protein subunit cytochrome $\mathrm{C}$ complex III. The point mutation caused amino acid substitution (i.e., Ala $>$ Thr) or just synonymous mutation. A peculiar phenomenon is the similarity of bases where mutation occurs in the Cytb region of the M5 and M6 gynogens. Since mutation is expected to be random, the occurrence of mutations of similar bases in the Cytb region might be due to the sensitivity of certain regions of $\mathrm{Cytb}$ to external stress. Under natural conditions, nonsynonymous mutation or deletion occurs in mtDNA due to environmental stresses [28]. Haplotype variation is another possible cause of mutations in similar bases between the M5 and M6 groups. At the 697th base, the M5 offspring has a G to A mutation, whereas those of M6 A to $\mathrm{G}$ mutation. This indicates that the mutation in base 697 is more likely to be the result of a haplotype variation between the M5 and M6 maternal parents.

The mutation rate at each site was calculated by using a formula by HaagLiautard et al. [29]:

$$
\mu=\sum_{i}(d i / t b)
$$

where $\mu$ is the mutation rate, $d i$ is the rate of individual observed mutations in the examined individuals, $b$ is the total number of bases of examined individuals, and $t$ is the number of generations (in this case, 1 ).

The calculated mutation rates were from $4.9 \times 10^{-6}$ to $3.1 \times 10^{-5}$ in the Cytb region and $1.8 \times 10^{-5}$ in the $\mathrm{D}$-loop region. These values were higher than the rate calculated in Drosophila, $6.3 \times 10^{-8}$ to $9.2 \times 10^{-8}$ (Haag-Liautard et al. 2008). 
Mutation rates more than two orders of magnitude higher were observed in masu salmon from Mano River near to FDNPP. These results suggest that exposure to radioactive Cs causes base exchanges of DNA. However, the observed mutations do not induce any that would cause severe results such as death. Each sequence observed in this study has been registered in the DNA database even if these base substitutions led to amino acid substitutions (GenBank accession numbers AB291986, AF125210, AF429776, LC098721, LC100136, and LC100137). Gynogenesis removes lethal genes, as a homozygous individual with a lethal gene cannot survive the early stage of development, whereas a nonlethal mutation can be carried by surviving individuals. Evidence of a mutation in the Cytb region of larvae from the wild might be a synonymous mutation that does not affect any morphological function despite the amino acid change. However, since the larval phenotype has not been investigated in detail, there is no strong evidence to expect that radioactive cesium contamination in eggs does not cause morphological changes in offspring. Of course, we did not examine the sequences in individuals that could not survive until the swim-up stage. It is necessary to examine individuals in different stages of development.

\subsection{Future Studies}

The effect of radioactive Cs on genetic materials have not been sufficiently studied. Estimation of the mutation rate of aquatic organisms in natural conditions will be important in determining the effect of radiation on the ecosystem. The present study is the first attempt to estimate the mutation rate in an aquatic organism in an area contaminated with radionuclides from FDNPP.

High levels of radioactive Cs are still observed in the rivers of the Abukuma Mountains of Fukushima. Freshwater fishes have continued to live in these areas after the accident occurred and the situation will continue for a long time. The Japanese Government decided to continue the use of nuclear power plants in the future. This decision suggests that an in-depth response to a nuclear accident is needed. Therefore, it is necessary to monitor living conditions such as radioactive Cs concentration in this area, as well as the health conditions of fishes that live there.

Acknowledgments We are grateful to the staff members of the Fukushima Prefectural Inland Water Fisheries Experimental Station for their help with sample processing and collection. We thank all of the fishery workers in Fukushima Prefecture who helped us to collect masu salmon. This work was supported in part by JSPS KAKENHI Grant Number 25252035. 


\section{References}

1. Honda MC, Kawakami H, Watanabe S et al (2013) Fukushima-derived radiocesium in western North Pacific sediment traps. Biogeosci Discuss 10:2455-2477. https://doi.org/10.5194/ bgd-10-2455-2013

2. Kumamoto T, Aoyama M, Hamajima $Y$ et al (2015) Impact of Fukushima-derived radiocesium in the western North Pacific Ocean about ten months after the Fukushima Dai-ichi nuclear power plant accident. J Environ Radioact 140:114-122. https://doi.org/10.1016/j. jenvrad.2014.11.010

3. Masson O, Ieringer J, Barttich E et al (2016) Variation in airborne 134Cs, 137Cs, particulate $131 \mathrm{I}$ and $7 \mathrm{Be}$ maximum activities at high-altitude European locations after the arrival of Fukushima-labeled air masses. J Environ Radioact 162:14-22. https://doi.org/10.1016/j. jenvard.2016.05.004

4. Shigenobu T, Fujimoto K, Ambe D et al (2014) Radiocesium contamination of greenlings (Hexagrammos otakii) off the coast of Fukushima. Nat Sci Rep 4:6851. https://doi.org/10.1038/ srep06851

5. Tateda Y, Tsumune D, Tsubono $\mathrm{T}$ et al (2015) Radiocesium biokinetics in olive flounder inhabiting the Fukushima accident-affected Pacific coastal waters of eastern Japan. J Environ Radioact 147:130-141. https://doi.org/10.1016/j.jenvrad.2015.05.025

6. Yoshihara T, Matsumura H, Hashida SN et al (2013) Radiocesium contaminations of 20 wood species and corresponding gamma-ray dose rates around the canopies at 5 months after the Fukushima nuclear power plant accident. J Environ Radioact 115:60-68. https://doi. org/10.1016/j.jenvrad.2012.07.002

7. da Cruz AD, de Melo e Silva D, da Silva CC et al (2008) Microsatellite mutations in the offspring of irradiated parents 19 years after the Cesium-137 accident. Mutat Res/Genet Toxicol Environ Mutagen 652(2):175-179. https://doi.org/10.1016/j.mrgentox.2008.02.002

8. Kamiguchi T, Tateno H (2002) Radiation- and chemical-induced structural chromosome aberrations in human spermatozoa. Mutat Res/Fundam Mol Mech Mutagen 504:184-191. https:// doi.org/10.1016/S0027-5107(02)00091-X

9. Muller HJ (1922) X-ray induced mutation of Drosophila virilis. Science 66:84-87

10. Casarett AP (1968) Radiation biology. Prentice-Hall, New Jersey

11. Schröder JH (1969) X-ray-induced mutations in the poeciliid fish, Lebistes reticulatus Peters. Mutat Res 7:75-90

12. Hyodo-Toguchi Y, Egami N (1969) Changes in dose-survival time relationship after $\mathrm{X}$-irradiation during embryonic development in the fish, Oryzias latipes. J Radiat Res 10:121-125

13. Kikuchi S, Egami N (1983) Effects of $r$-irradiation on the rejection of transplanted scale melanophores in the teleost, Oryzias latipes. Dev Comp Immunol 7:51-58

14. Chino M, Nakayama H, Nagai H et al (2011) Preliminary estimation of release amounts of $131 \mathrm{I}$ and ${ }^{137} \mathrm{Cs}$ accidentally discharged from the Fukushima Daiichi nuclear power plant into the atmosphere. J Nuclear Sci Tech 48:1129-1134

15. Stohl A, Seibert P, Wotawa G et al (2012) Xenon-133 and caesium-137 releases into the atmosphere from the Fukushima Dai-ichi nuclear power plant: determination of the source term, atmospheric dispersion, and deposition. Atmos Chem Phys 12:2313-2343

16. Povinec PP, Gera M, Holy K et al (2013) Dispersion of Fukushima radionuclides in the global atmosphere and the ocean. Appl Tadiat Isot 81:383-392

17. Zaleaska T, Suplinska M (2013) Fish pollution with anthropogenic 137Cs in the southern Baltic Sea. Chemosphere 90:1760-1766. https://doi.org/10.1016/jchemosphere.2012.07.012

18. Iwagami S, Tsujimura M, Onda $Y$ et al (2017) Contribution of radioactive 137Cs discharge by suspended sediment, coarse organic matter, and dissolved fraction from a headwater catchment in Fukushima after the Fukushima Dai-ichi nuclear power plant accident. J Environ Radioact 166:466-474. https://doi.org/10.1016/j.jenvrad.2016.07.025 
19. Yoshimura M, Yokoduka T (2014) Radioactive contamination of fishes in lake and streams impacted by the Fukushima nuclear power plant accident. Sci Total Environ 482-483:184192. https://doi.org/10.1016/j.scitotenv.2014.02.118

20. Wada T, Tomiya A, Enomoto M et al (2016) Radiological impact of the nuclear power plant accident on freshwater fish in Fukushima: an overview of monitoring results. J Environ Radioact 151:144-155. https://doi.org/10.1016/j.jenvrad.2015.09.017

21. Kitanishi S, Edo K, Yamamoto T et al (2012) Fine scale relationships between sex, life history, and dispersal of masu salmon. Ecol Evol 2:920-929. https://doi.org/10.1002/ece3.228. et al 2012

22. Ohkuma K, Ishida Y, Rassadnikov OA et al (2000) Distribution and biological characters of pink (Oncorhynchus gorbuscha) and masu salmon (O. masou) in the Sea of Japan. Bull Natl Salmon Resour Cent 3:1-10

23. Wang L, Kuwahara Y, Li L et al (2007) Analysis of common deletion (CD) and a novel deletion of mitochondrial DNA induced by ionizing radiation. Int J Radiat Biol 83:433-442

24. Ashley MV, Laipis PJ, Hauswirth WW (1989) Rapid segregation of heteroplasmic bovine mitochondria. Nucleic Acids Res 17:7325-7331

25. Schwartz M, Vissing J (2002) Paternal inheritance of mitochondrial DNA. N Engl J Med 347:576-580

26. Thorgaard GH, Allen SK (1986) Chromosome manipulation and markers in fishery management. In: Ryman N, Utter F (eds) Population genetics and fishery management. Washington Sea Grant Program, Distributed by University of Washington Press, Seattle, pp 319-331

27. Olsen JB, Wilson SL, Kretschmer EJ, Jones KC, Seeb JE (2009) Characterization of 14 tetranucleotide microsatellite loci derived from sockeye salmon. Mol Ecol 9:2155-2234

28. Shirai K, Inomata N, Mizoiri S et al (2014) High prevalence of non-synonymous substitutions in mtDNA of cichlid fishes from Lake Victoria. Gene 552:239-245. https://doi.org/10.1016/j. gene.2014.09.039

29. Haag-Liautard C, Coffey N, Houle D et al (2008) Direct estimation of the mitochondrial DNA mutation rate in Drosophila melanogaster. PLoS Biol 6(8):1706-1714. https://doi. org/10.1371/journal.pbio.0060204

Open Access This chapter is licensed under the terms of the Creative Commons Attribution 4.0 International License (http://creativecommons.org/licenses/by/4.0/), which permits use, sharing, adaptation, distribution and reproduction in any medium or format, as long as you give appropriate credit to the original author(s) and the source, provide a link to the Creative Commons license and indicate if changes were made.

The images or other third party material in this chapter are included in the chapter's Creative Commons license, unless indicated otherwise in a credit line to the material. If material is not included in the chapter's Creative Commons license and your intended use is not permitted by statutory regulation or exceeds the permitted use, you will need to obtain permission directly from the copyright holder.

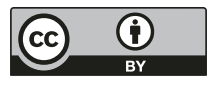

